\title{
Microglial Activation and $\beta$-Amyloid Deposit Reduction Caused by a Nitric Oxide-Releasing Nonsteroidal Anti-Inflammatory Drug in Amyloid Precursor Protein Plus Presenilin-1 Transgenic Mice
}

\author{
Paul T. Jantzen, ${ }^{1}$ Karen E. Connor, ${ }^{1}$ Giovanni DiCarlo, ${ }^{1}$ Gary L. Wenk, ${ }^{3}$ John L. Wallace, ${ }^{4}$ Amyn M. Rojiani, ${ }^{2}$ \\ Domenico Coppola, ${ }^{2}$ Dave Morgan, ${ }^{1}$ and Marcia N. Gordon ${ }^{1}$ \\ Departments of ${ }^{1}$ Pharmacology and 2 Interdisciplinary Oncology, Alzheimer's Research Laboratory, University of South \\ Florida, Tampa, Florida 33612, 3Division of Neural Systems, Memory, and Aging, University of Arizona, Tucson, Arizona \\ 85724, and ${ }^{4}$ Department of Pharmacology and Therapeutics, University of Calgary, Calgary, Alberta, T2N 4N1, Canada
}

3- 4- (2-Fluoro- $\alpha$-methyl- [1,1'-biphenyl] -4-acetyloxy)-3-methoxyphenyl]-2-propenoic acid 4-nitrooxy butyl ester (NCX-2216), a nitric oxide (NO)-releasing derivative of the cyclooxygenase-1preferring nonsteroidal anti-inflammatory drug (NSAID) flurbiprofen, dramatically reduced both $\beta$-amyloid $(A \beta)$ loads and Congo red staining in doubly transgenic $(\mathrm{Tg})$ amyloid precursor protein plus presenilin-1 mice when administered at $375 \mathrm{ppm}$ in diet between 7 and 12 months of age. This reduction was associated with a dramatic increase in the number of microglia expressing major histocompatibility complex-II antigen, a marker for microglial activation. In contrast, ibuprofen at 375 ppm in diet caused modest reductions in $A \beta$ load but not Congo red staining, suggesting that the effects of this nonselective NSAID were restricted primarily to nonfibrillar deposits. We detected no effects of the cyclooxygenase-2-selective NSAID celecoxib at $175 \mathrm{ppm}$ on amyloid deposition. In short-term studies of 12-month-old Tg mice, we found that the microglia-activating properties of NCX$2216\left(7.5 \mathrm{mg} \cdot \mathrm{kg}^{-1} \cdot \mathrm{d}^{-1}\right.$, s.c.) were present after 2 weeks of treatment. Microglia were not activated by NCX-2216 in non-Tg mice lacking $A \beta$ deposits, nor were microglia activated in $\mathrm{Tg}$ animals by flurbiprofen $\left(5 \mathrm{mg} \cdot \mathrm{kg}^{-1} \cdot \mathrm{d}^{-1}\right)$ alone. These data are consistent with the argument that activated microglia can clear $A \beta$ deposits. We conclude that the NO-generating component of NCX-2216 confers biological actions that go beyond those of typical NSAIDs. In conclusion, NCX-2216 is more efficacious than ibuprofen or celecoxib in clearing $A \beta$ deposits from the brains of Tg mice, implying potential benefit in the treatment of Alzheimer's dementia.

Key words: Alzheimer's disease; microglia; MHC-II; $\beta$-amyIoid; NSAIDs; transgenic mice
Although it is clear that microglia are intimately involved in the inflammatory response of the brain, especially to the amyloid deposits in Alzheimer's disease (AD) (Akiyama et al., 2000), their role in the pathogenesis of the disease is less certain. Microglia have been argued to be responsible for either $\beta$-amyloid (A $\beta$ ) deposition (Frackowiak et al., 1992; Wegiel et al., 1996) or A $\beta$ clearance (Schenk et al., 1999; Bacskai et al., 2000; Bard et al., 2000; Chung et al., 1999; Wyss-Coray et al., 2001). Microglia are normally kept in a tightly regulated inactive state; activation is typically short-lived and protective toward neurons and other neural components (Kreutzberg, 1996; Moore and Thanos, 1996; Minghetti et al., 1999). However, microglia are chronically active in late-stage AD. Activated microglia can, in their response to insult, release reactive oxygen and nitrogen species, with one major consequence being damage to the local cellular environment (Rogers et al., 1996; McGeer and McGeer, 1998). The activation of microglia is probably a response to the deposition of fibrillar $\mathrm{A} \beta$ in $\mathrm{AD}$, however the activation is not a necessary correlate of $\mathrm{A} \beta$ deposition. Most autopsy series involving AD patients and nondemented elderly individuals demonstrate cases

Received Sept. 10, 2001; revised Dec. 4, 2001; accepted Dec. 17, 2001.

This work was supported by National Institutes of Health Grant AG 15490 (M.N.G.) and the Benjamin Trust (D.M.). We thank Piero del Soldato of Nicox, S.A. for the generous donation of NCX-2216 and Ennio Ongini for his thoughtful comments on this work.

Correspondence should be addressed to Dave Morgan, University of South Florida College of Medicine, MDC Box 9, Tampa, FL 33612. E-mail: dmorgan@hsc.usf.edu.

Copyright (C) 2002 Society for Neuroscience $\quad 0270-6474 / 02 / 222246-09 \$ 15.00 / 0$ with the classic pathological hallmarks of AD but without signs of dementia before death (Crystal et al., 1988; Snowdon, 1997). These individuals also fail to exhibit microglial reactivity to the A $\beta$ deposits (Lue et al., 1996; Sasaki et al., 1997).

In recent years, it has been reported that chronic nonsteroidal anti-inflammatory drug (NSAID) use is able to delay the onset and possibly reduce the risk of AD (Breitner, 1996; Mackenzie, 1996; Mackenzie et al., 1998). Although the NSAID data are encouraging, recommendations for chronic NSAID therapy in healthy elderly individuals are tempered by the well documented risk of gastrointestinal (GI) bleeding and ulceration (James, 1999). To reduce the risk of GI injury, new classes of NSAIDs have been developed, including selective inhibitors of cyclooxygenase-2 (COX2) and nitric oxide (NO)-donating NSAIDs (nitro-NSAIDs) (Wallace et al., 1994; Del Soldato et al., 1999). NO plays multiple roles in different physiological systems, including the brain, where it is potentially a critical retrograde transmitter (Navarra et al., 2000; Chowdhary and Townend, 2001; Grassi and Pettorossi, 2001; Napoli and Ignarro, 2001). The nitro-NSAID used in these studies, 3-[4-(2-fluoro- $\alpha$-methyl-[1,1'-biphenyl]-4-acetyloxy)-3-methoxyphenyl]-2-propenoic acid 4-nitrooxy butyl ester (NCX-2216), consists of a nitroxybutyl ester moiety coupled to flurbiprofen via a methoxyphenyl (ferulic acid) linker.

In these studies we used a doubly transgenic ( $\mathrm{Tg}$ ) mouse model of amyloid deposition (Holcomb et al., 1998) to test the working hypothesis that the benefit of NSAID use in diminishing the risk of $\mathrm{AD}$ is attributable to suppression of the microglial response. 
We compared the effects of a prototypical and nonselective NSAID demonstrated previously to reduce $A \beta$ deposition, ibuprofen (Lim et al., 2000), with the COX2-selective inhibitor celecoxib and the NO-releasing NSAID NCX-2216. Unexpectedly, we found that the NO-releasing NSAID activated microglia. In parallel, we also found that this agent reduced $A \beta$ loads more than the other agents.

\section{MATERIALS AND METHODS}

Transgenic mice overexpressing Swedish mutant amyloid precursor protein (APP; Tg2576; K670N/M671L) (Hsiao et al., 1996) and mutant presenilin-1 (PS1; line 5.1; M146L) (Duff et al., 1996) were crossed to produce double mutant transgenic APP + PS1 mice. The Alzheimer's-like phenotype present in these mice has been well characterized (Holcomb et al., 1998, 1999b; McGowan et al., 1999; Gordon et al., 2001). Chronic NSAID diet-treated animals were fed drug-containing or control rat chow between 7 and 12 months of age. Short-term treatments used 12-month-old mice; the mice were injected daily (subcutaneously) for $14 \mathrm{~d}$ with 19:1 castor oil:DMSO vehicle, $7.5 \mathrm{mg} \cdot \mathrm{kg}^{-1} \cdot \mathrm{d}^{-1} \mathrm{NCX}-2216$, or $5 \mathrm{mg} \cdot \mathrm{kg}^{-1} \cdot \mathrm{d}^{-1}$ flurbiprofen based on previous work in rats (HaussWegrzyniak et al., 1999a).

In the long-term administration study, we selected the dosage of ibuprofen (375 ppm in diet or $\sim 62.5 \mathrm{mg} \cdot \mathrm{kg}^{-1} \cdot \mathrm{d}^{-1}$ per animal; $n=7$ transgenic and 8 nontransgenic mice) that Lim et al. (2000) found to be effective at reducing $\mathrm{A} \beta$. We estimated an equivalent dosage of celecoxib $\left(175 \mathrm{ppm}\right.$ or $\sim 30 \mathrm{mg} \cdot \mathrm{kg}^{-1} \cdot \mathrm{d}^{-1}$ per animal; $n=7$ transgenic and 7 nontransgenic mice) based on the relative human daily dosages of celecoxib and ibuprofen. We similarly estimated an equivalent dosage of NCX-2216 (375 ppm in diet or $\sim 62.5 \mathrm{mg} \cdot \mathrm{kg}^{-1} \cdot \mathrm{d}^{-1}$ per animal; $n=7$ transgenic mice) so that the ratio of the mass of flurbiprofen consumed relative to ibuprofen in the first diet would approximate the relative human dosages of these drugs. We recognize that short of actually measuring the degree of mouse brain COX inhibition over a $24 \mathrm{hr}$ period, we cannot claim that the dosage of each drug is equivalent with respect to $\mathrm{COX}$ inhibition. However, we hoped that by administering mass ratios similar to those typically administered to humans, we would achieve relative brain levels that were comparable with those typically found in humans using these medications. Animals were given food and water ad libitum and kept on a $12 \mathrm{hr}$ light/dark cycle.

Nicox, S.A. (Sophia-Antipolis, France) generously donated NCX2216. We purchased ibuprofen from Sigma (St. Louis, MO). For celecoxib, we used Celebrex capsules (GD Searle \& Co., Chicago, IL). All agents were compounded with rodent chow into pellets (base diet equaled a modified NIH-31 diet; Harlan, Bicester, UK). Food was kept refrigerated and placed in the food hoppers every other day. Dosages are based on a the typical consumption rate of $5 \mathrm{gm} / \mathrm{d}$ per mouse (thus the numbers given above are approximate). Antibodies came from multiple sources: $\mathrm{A} \beta$ was provided by Dr. Paul Gottschall (University of South Florida), CD-11 (complement receptor-3; antibody Mac-1) rat antimouse monoclonal IgG was obtained from Serotec (Oxford, UK), and major histocompatibility complex (MHC)-II rat anti-mouse monoclonal IgG was provided by PharMingen (San Diego, CA). Secondary antibodies were biotinylated anti-rat $\mathrm{IgG}$ and biotinylated goat anti-rabbit IgG and were visualized using a Vectastain avidin-biotin complex kit (all from Vector Laboratories, Burlingame, CA). All other compounds were from Sigma. Reagent grade type I water was used in all procedures.

Within $24 \mathrm{hr}$ of the last drug administration, animals were overdosed with pentobarbital $(100 \mathrm{mg} / \mathrm{kg}$, i.p.) and perfused transcardially with 25 $\mathrm{ml}$ of normal $(0.9 \%)$ saline. The brains were rapidly removed and bisected sagittally; the left hemisphere was immersed in freshly depolymerized $4 \%$ paraformaldehyde for $24 \mathrm{hr}$ (right hemispheres were dissected and frozen). The left hemispheres were then cryoprotected by successive $24 \mathrm{hr}$ immersions in 10, 20, and 30\% sucrose in Sorenson's phosphate buffer immediately before sectioning. Fixed, cryoprotected brains were frozen and sectioned in toto in the horizontal plane at $25 \mu \mathrm{m}$ using a sliding microtome, collected serially, and stored at $4^{\circ} \mathrm{C}$ in Dulbecco's PBS with sodium azide for subsequent immunohistochemistry and histology. Systematic uniform random sets of sections with $300 \mu \mathrm{m}$ spacing were used for all staining. Sets were stained histologically for Nissl substance using $0.05 \%$ cresyl violet and for amyloid deposits by the Congo red method. Immunohistochemistry was performed on floating sections using specific antibodies to identify cellular and noncellular markers. $\mathrm{A} \beta$ deposits, both fibrillar and diff use, were visualized using a panspecific rabbit polyclonal antibody raised against the $\mathrm{A} \beta_{1-40}$ peptide. Microglia were visualized with two antibodies: anti-CR3 and anti-MHCII. All immunohistochemistry was visualized with avidin-biotin-horse-

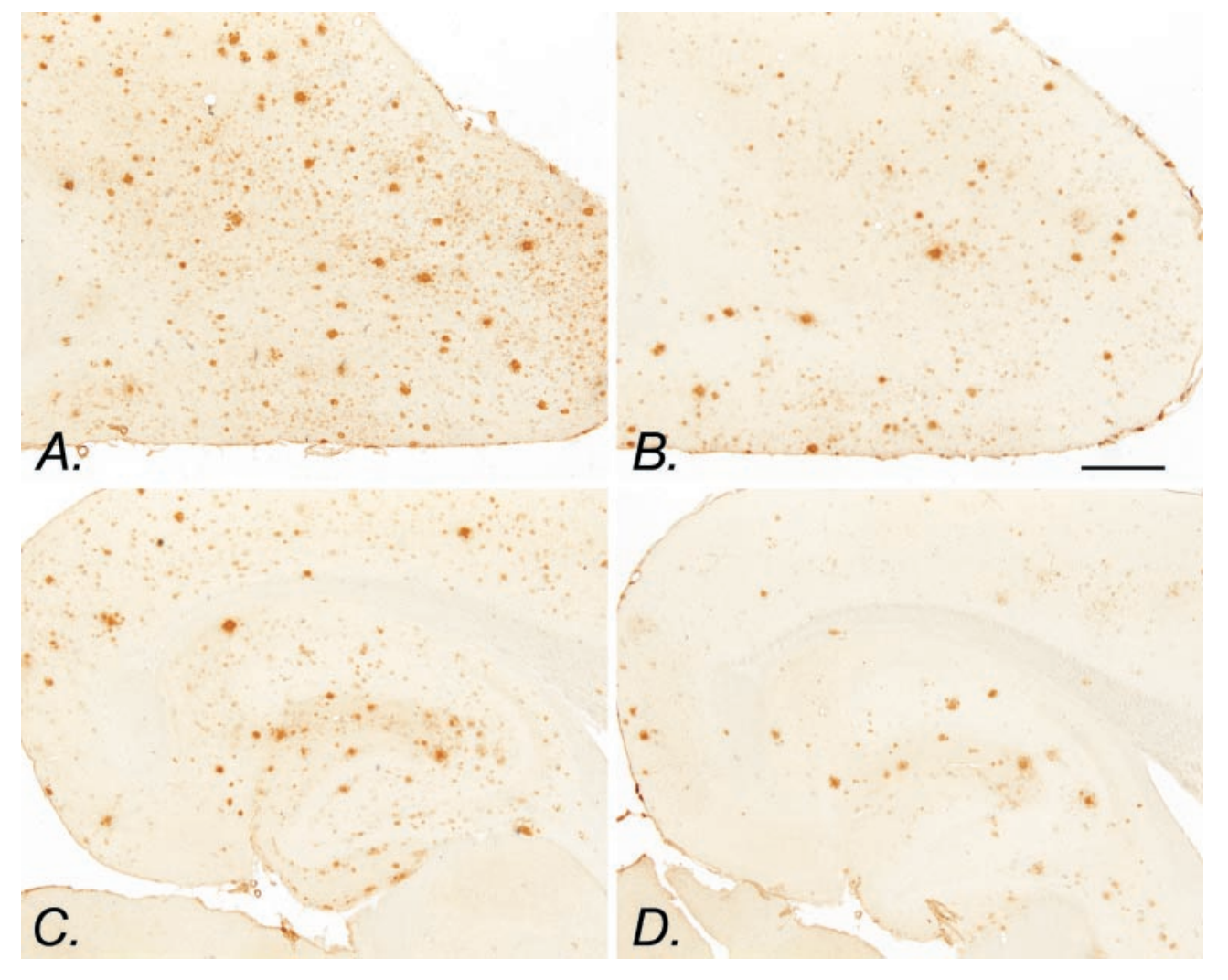

Figure 1. $\mathrm{A} \beta$ immunohistochemistry in control and NCX-2216-treated transgenic mice. $\mathrm{A} \beta$ immunohistochemistry of the frontal cortex $(A)$ and hippocampus $(C)$ of an APP $+\mathrm{PS} 1$ transgenic mouse fed the control diet from 7 to 12 months of age is shown. $A \beta$ immunohistochemistry of the frontal cortex $(B)$ and hippocampus $(D)$ of an APP + PS1 transgenic mouse fed $375 \mathrm{ppm}$ NCX2216 in diet from 7 to 12 months of age is also shown. Scale bar, $1 \mathrm{~mm}$. 
radish peroxidase and DAB with nickel enhancement for color development (except for $\mathrm{A} \beta$ staining, which omitted the nickel enhancement). Sections stained for microglial markers were secondarily stained with Congo red to localize amyloid deposits in a $\beta$-sheet configuration. Representative sections from each genotype/treatment group were assayed with the primary antibody omitted to demonstrate nonspecific reaction product formation; these sections displayed negligible staining.

Two regions were examined quantitatively in this experiment: the hippocampus and the frontal cortex. The hippocampus was delimited by the corpus callosum laterally and posteriorly, the ventricle and thalamus medially, and the fimbria/fornix anteriorly. The frontal cortex is defined as all cortical tissue medial and anterior to the most anterior limit of the corpus callosum on each hemisection, and ventral to the initial appearance of the hippocampal formation in the section set. This region is limited medially by the midline.

The unbiased sampling methods of West et al. (1991) were used to select sections for quantitative analysis. Because the measured outcome of total volume occupied by congophilic material and by $\mathrm{A} \beta$ immunocytochemical (ICC) reaction product (ICC-RP) has digital properties (i.e., positive/negative staining readily discriminable by visual inspection), these stains were quantified using point-counting methods, assisted by a computer-based system, the Stereologer (Systems Planning and Analysis, Alexandria, VA). Briefly, the equipment consisted of an X-Y-Z motorized stage (MS-2000; Applied Scientific Instrumentation, Eugene, OR) and color video camera connected to a microscope (Olympus BH-2; Olympus Optical, Tokyo, Japan). The digital output of the camera was processed and displayed by a Macintosh PowerMac 8500/120AV computer (Apple Computers, Cupertino, CA). The Stereologer software controlled operation of the system. Total microglial presence (total immunoreactivity of CR3 ICC-RP) was quantified using the videodensitometric procedures detailed by Gordon et al. (1997). This method uses the V150 image analysis system (Oncor, San Diego, CA) to segment immunostained pixels using hue-saturation-intensity (HSI) characteristics. Total immunoreactivity is the area occupied by immunopositive pixels multiplied by the optical density of those pixels. Because the number of MHC-II-positive microglial profiles in vehicle-treated mice was too low to be reliably estimated using a reasonable number of disectors, identifiable profiles in all animals were manually counted and are reported as average number of MHC-II-positive profiles per section. Between 10 and 15 sections per region per animal were examined for each measure.

At necropsy, gastrointestinal tracts (stomach, small intestine, and large intestine) of all mice were collected and post-fixed for $24 \mathrm{hr}$ in $4 \%$ paraformaldehyde. The major portion of the gastrointestinal tract was embedded in paraffin, sectioned, and stained with hematoxylin and eosin. These sections were independently evaluated by three investigators who were unaware of the treatment conditions.

To assess possible treatment-related differences in $\mathrm{A} \beta$ deposition and microglial number and total immunoreactivity, the measurements for each brain region of each subject were analyzed by ANOVA, followed by least significant difference post hoc analyses using the computer program Statview (SAS Institute, Cary, NC).

\section{RESULTS}

The anterior cortex and hippocampus of APP + PS1 and nontransgenic mice were examined after 5 months of ad libitum administration of NCX-2216, ibuprofen, celecoxib, or the base diet. As expected, the transgenic mice accumulated considerable $\mathrm{A} \beta$ in the cerebral cortex and hippocampus as they reached 12 months of age (Fig. $1 A, C$ ). Mice treated with NCX-2216 between 7 and 12 months of age had a reduction in the amounts of amyloid found in these structures (Fig. $1 B, D$ ). When quantified by stereology, there was a significant effect of drug treatment in the cerebral cortex (ANOVA; $F_{(3,21)}=5.7 ; p<0.005$ ) and hippocampus $\left(F_{(3,21)}=5.9 ; p<0.005\right)$. The greatest reduction was found in the mice treated with NCX-2216; these mice displayed $40-45 \%$ less $\mathrm{A} \beta$ load than mice given control diets $(p<0.001)$ (Fig. $2 A, B)$. Ibuprofen also reduced the A $\beta$ load by $20-25 \%$, with a significant reduction in the cerebral cortex $(p<0.025)$ (Fig. $2 A)$. The mean values for celecoxib-treated mice were $15-20 \%$ lower than the
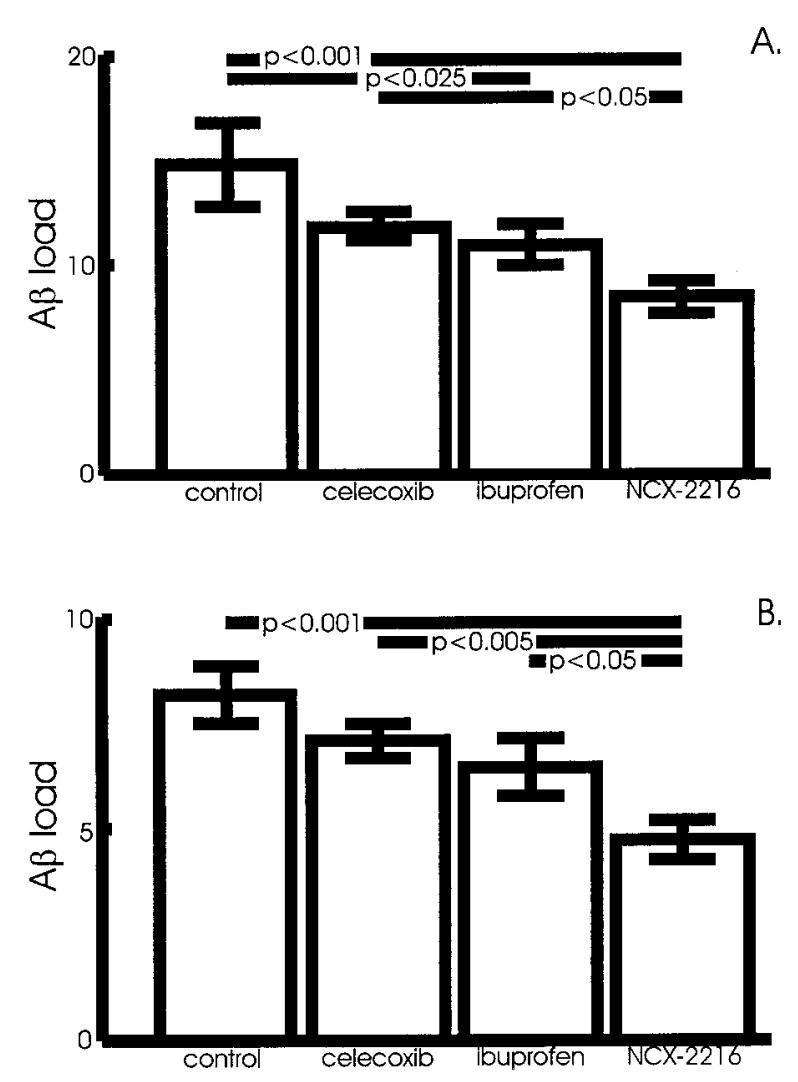

Figure 2. $\mathrm{A} \beta$ load in the anterior cortex and hippocampus of NCX-2216treated mice. The $\mathrm{A} \beta$ load is the percentage of the cross-sectional area occupied by the immunohistochemical reaction product. NCX-2216treated $\mathrm{APP}+\mathrm{PS} 1$ mice have significantly less $\mathrm{A} \beta$ in both the cortex $(A)$ and hippocampus $(B)$, as demonstrated by immunohistochemistry, compared with mice treated with ibuprofen (hippocampus, $p<0.05$ ), celecoxib (cortex, $p<0.05$; hippocampus, $p<0.005$ ), or fed the control diet (cortex, $p<0.001$; hippocampus, $p<0.001$ ). In the cortex, ibuprofen significantly reduced $\mathrm{A} \beta$ load as well $(p<0.025)$ compared with mice fed the control diet.

mean for control animals, but there was no significant difference with the statistical power of the present study (Fig. $2 A, B$ ).

A similar result was observed for the Congo red-stained sections, although the reductions are restricted to the NCX-2216treated mice. The numbers of congophilic deposits in the cerebral cortex and hippocampus were reduced in the mice fed NCX-2216 between 7 and 12 months of age, and the deposits that were present appear smaller (Fig. 3). ANOVA revealed a significant effect of drug treatment on the Congo red-stained area in the cerebral cortex $\left(F_{(3,21)}=6.7 ; p<0.005\right)$ (Fig. $\left.4 A\right)$ and in the hippocampus $\left(F_{(3,21)}=4.7 ; p<0.01\right)$ (Fig. $\left.4 B\right)$. Mean comparisons indicated reductions of $35-40 \%$ in both regions for the mice treated with NCX-2216 ( $p<0.01$ ) (Fig. 4A,B). In fact, the NCX-2216-treated mice had significantly lower Congo red staining than the other NSAID-treated groups in both structures $(p<0.02)$.

The most surprising result of this treatment was the effect of the drugs on microglial activation. NCX-2216 treatment dramatically increased the numbers of activated microglia that are stained with MHC-II antisera over the small numbers of cells visible in control transgenic mice (there were no detectable MHC-II-stained cells in one-half of the control mice) (Fig. $5 A, C)$. For the most part, these positively stained microglia were in association with congophilic amyloid deposits and absent in 


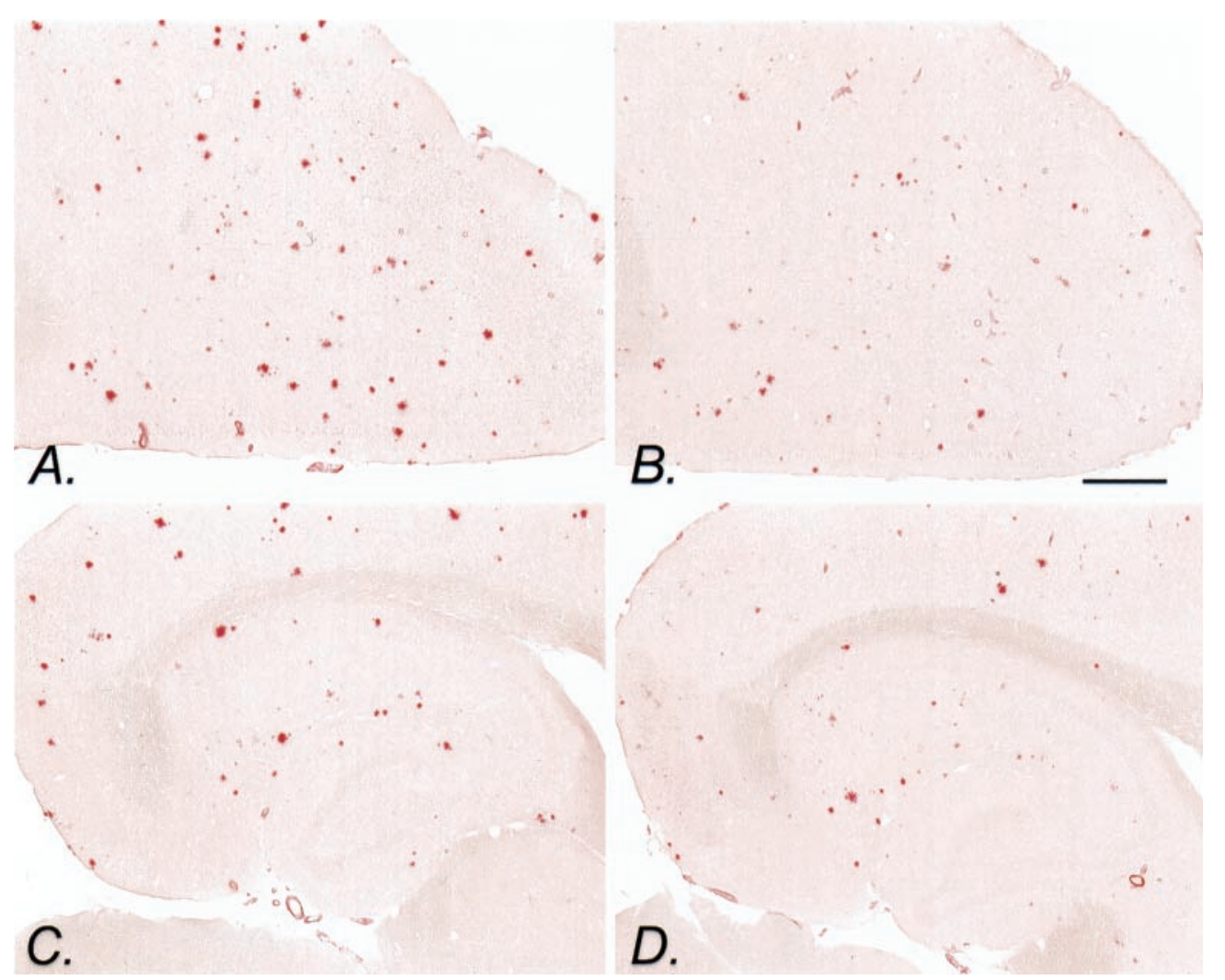

Figure 3. Congo red staining in NCX2216-treated transgenic mice. Shown is Congo red staining of the frontal cortex $(A)$ and hippocampus $(C)$ of an APP + PS1 transgenic mouse fed the control diet from 7 to 12 months of age. Congo red staining of the frontal cortex $(B)$ and hippocampus $(D)$ of an APP + PS1 transgenic mouse fed 375 ppm NCX-2216 in diet from 7 to 12 months of age is also shown. Scale bar, $1 \mathrm{~mm}$. regions lacking such deposits. In the anterior cortex of mice treated with NCX-2216, there was a significant increase in MHCII-positive cells over mice fed control diets $(p<0.05)$ (Fig. 6A). In the hippocampus, mice treated with NCX-2216 had more MHC-II-immunopositive profiles than all three other groups $(p<0.02)$ (Fig. 6B). In both structures, ibuprofen and celecoxib treatment resulted in a small but nonsignificant increase in the number of these cells compared with mice on control diets (Fig. 6).

We have also demonstrated that microglial expression of MHC-II can be elicited after shorter administrations of NCX2216. Subcutaneous injection of $7.5 \mathrm{mg} \cdot \mathrm{kg}^{-1} \cdot \mathrm{d}^{-1} \mathrm{NCX}-2216$ for 2 weeks increased the numbers of MHC-II-positive microglia in APP + PS1 transgenic mice at 12 months of age (Figs. 7A, $B$, $8 A$ ). Immunostaining for another microglial marker, CD11 (complement receptor-3 stained with the Mac-1 antibody), also appeared to be modified by the NCX-2216 treatment (Fig. 7C,D). However, in this case the main effect was greater staining intensity rather than increased numbers of stained cells (microglia express CD11 even when quiescent). To quantify this effect, we established an intensity threshold for the HSI segmentation that would not include resting microglia in the segmentation window. We then measured the area occupied by this intense reaction product (using a constant segmentation threshold for each section as described by Gordon et al., 1997), and found an increased staining area in the hippocampus of mice treated with NCX-2216 compared with control mice (Fig. $8 B)(p<0.05)$. Not surprisingly, there were no reductions in $\mathrm{A} \beta$ load or Congo red staining after this short treatment period (data not shown).

To understand the mechanism of this activation better, we examined APP-only transgenic mice at 12 months of age. Although these mice have considerably fewer $\mathrm{A} \beta$ deposits, there was still a significant effect of NCX-2216 on the numbers of MHC-
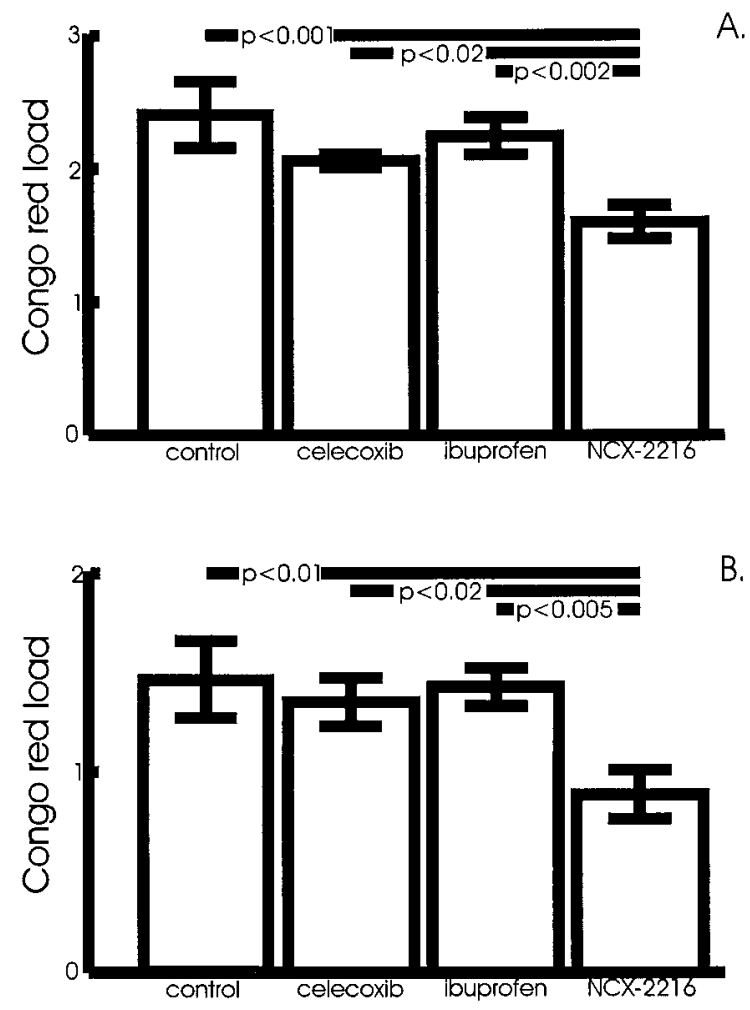

Figure 4. Amyloid load in the anterior cortex and hippocampus of NCX-2216-treated mice. Amyloid load is the percentage of the crosssectional area occupied by Congo red stain. NCX-2216-treated APP+PS1 mice have significantly less amyloid in both the cortex $(A)$ and hippocampus $(B)$, as demonstrated by Congo red staining, compared with mice treated with ibuprofen (cortex, $p<0.002$; hippocampus, $p<0.005$ ), celecoxib (cortex, $p<0.02$; hippocampus, $p<0.02$ ), or fed the control diet (cortex, $p<0.001$; hippocampus, $p<0.01$ ). 
Figure 5. MHC-II immunohistochemistry with Congo red counterstaining of NCX-2216-treated transgenic mice is shown. MHC-II immunohistochemistry (black reaction product) of the frontal cortex $(A)$ and hippocampus $(C)$ of an APP + PS1 transgenic mouse fed the control diet from 7 to 12 months of age is shown. MHC-II immunohistochemistry of the frontal cortex $(B)$ and hippocampus $(D)$ of an APP + PS1 transgenic mouse fed 375 ppm NCX-2216 in diet from 7 to 12 months of age is also shown. Scale bar, $100 \mu \mathrm{m}$.

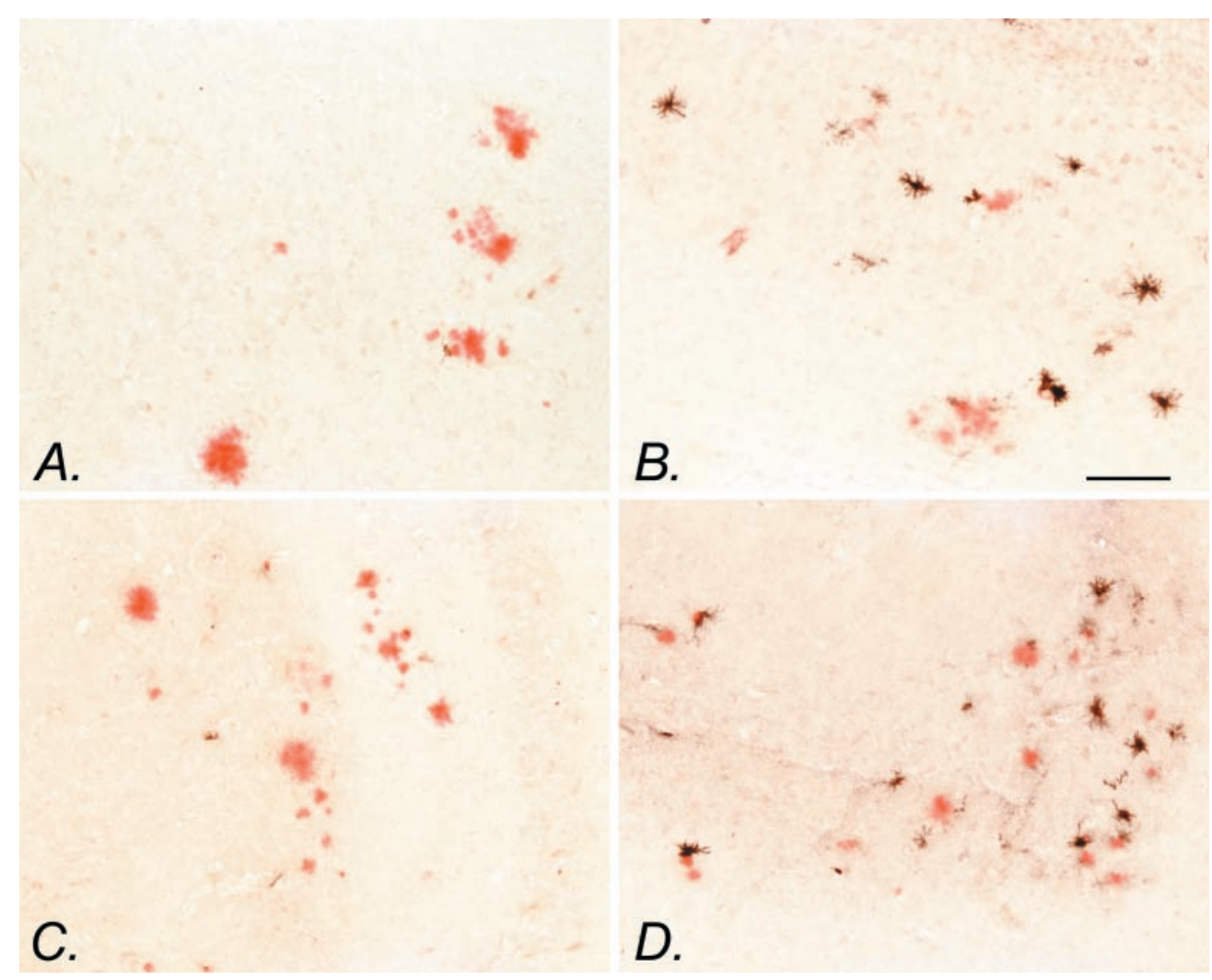

II-positive profiles (Fig. 9). This property of activating microglia is apparently not solely a function of the NSAID moiety of the molecule, because injections of flurbiprofen alone had no effect on the numbers of MHC-II-stained microglia (Fig. 9). Importantly, the activation of microglia by NCX-2216 involves an interaction with the AD phenotype of the mice. MHC-II-positive microglia were not found in nontransgenic mice treated with either NCX-2216 or vehicle (Fig. 9).

Histological examination of gastrointestinal tract sections in mice treated with NSAIDs for 5 months found degrees of erosions, gastritis, and ulcers in each treatment condition. Gastrointestinal erosions were found in 6 of 12 control mice, 4 of 13 mice treated with celecoxib, 1 of 7 mice administered NCX-2216, and 6 of 15 mice given ibuprofen. Gastritis was found in two of the celecoxib-treated mice, one NCX-2216-treated mouse, and five of the ibuprofen-treated mice. Ulcers were found in two of the NCX-2216 mice. Two ibuprofen-treated mice died during the course of the study, but no deaths were found in the other groups. None of the treatment groups lost weight over the course of the study, and there was no statistically significant difference in weight gain between the groups during the course of the study. In other studies, the parent of NCX-2216, flurbiprofen, led to severe gastropathy, weight loss, and in some instances death when administered to rats or mice for 2 weeks, indicating that the histopathology observed here was relatively benign (Wallace et al., 1994) (J. Wallace, unpublished observations).

\section{DISCUSSION}

The major finding of this study is that the nitric oxide-releasing NSAID NCX-2216 substantially reduced A $\beta$ loads in APP+PS1 transgenic mice. Ibuprofen also had an effect on diffuse $\mathrm{A} \beta$, confirming the original findings of Lim et al. (2000) in transgenic mice that overexpress only the APP transgene. Although NCX-
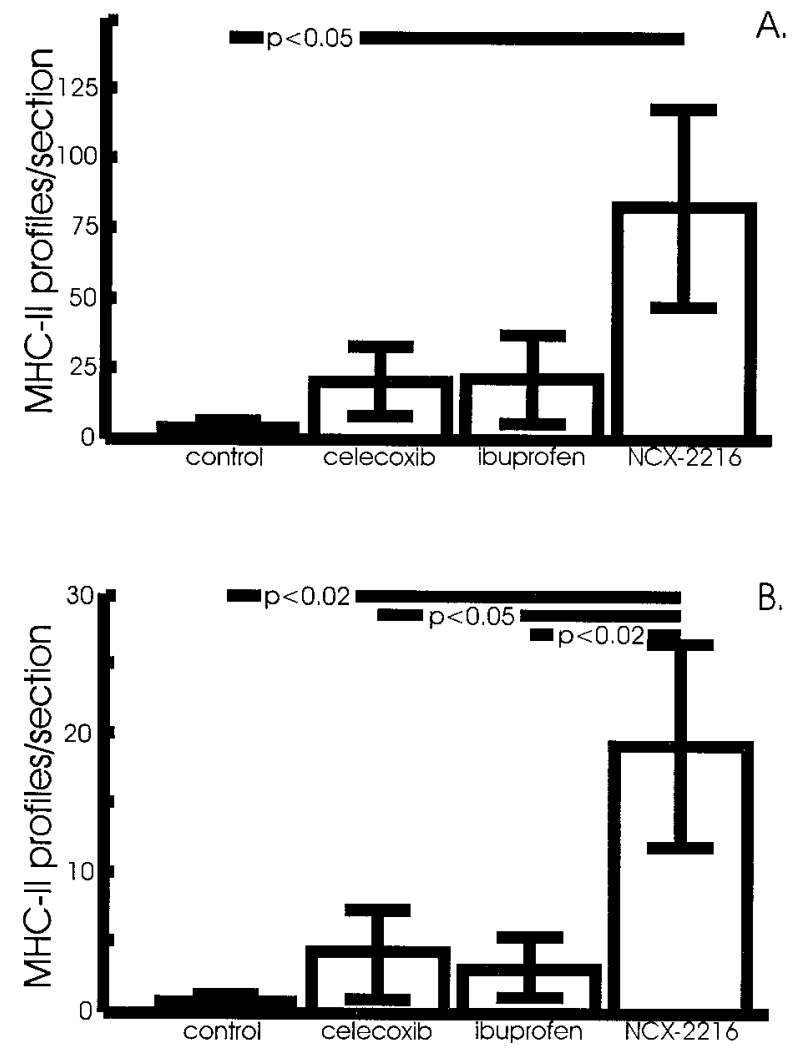

Figure 6. NCX-2216-treated APP+PS1 mice have larger numbers of MHC-II-positive microglia in the frontal cortex $(A)$ and hippocampus $(B)$ compared with mice fed a control diet (frontal cortex, $p<0.05$; hippocampus, $p<0.02$ ). Ibuprofen-treated mice have a small but not significant increase in the numbers of MHC-II-positive microglia in the anterior cortex compared with control-treated mice. 


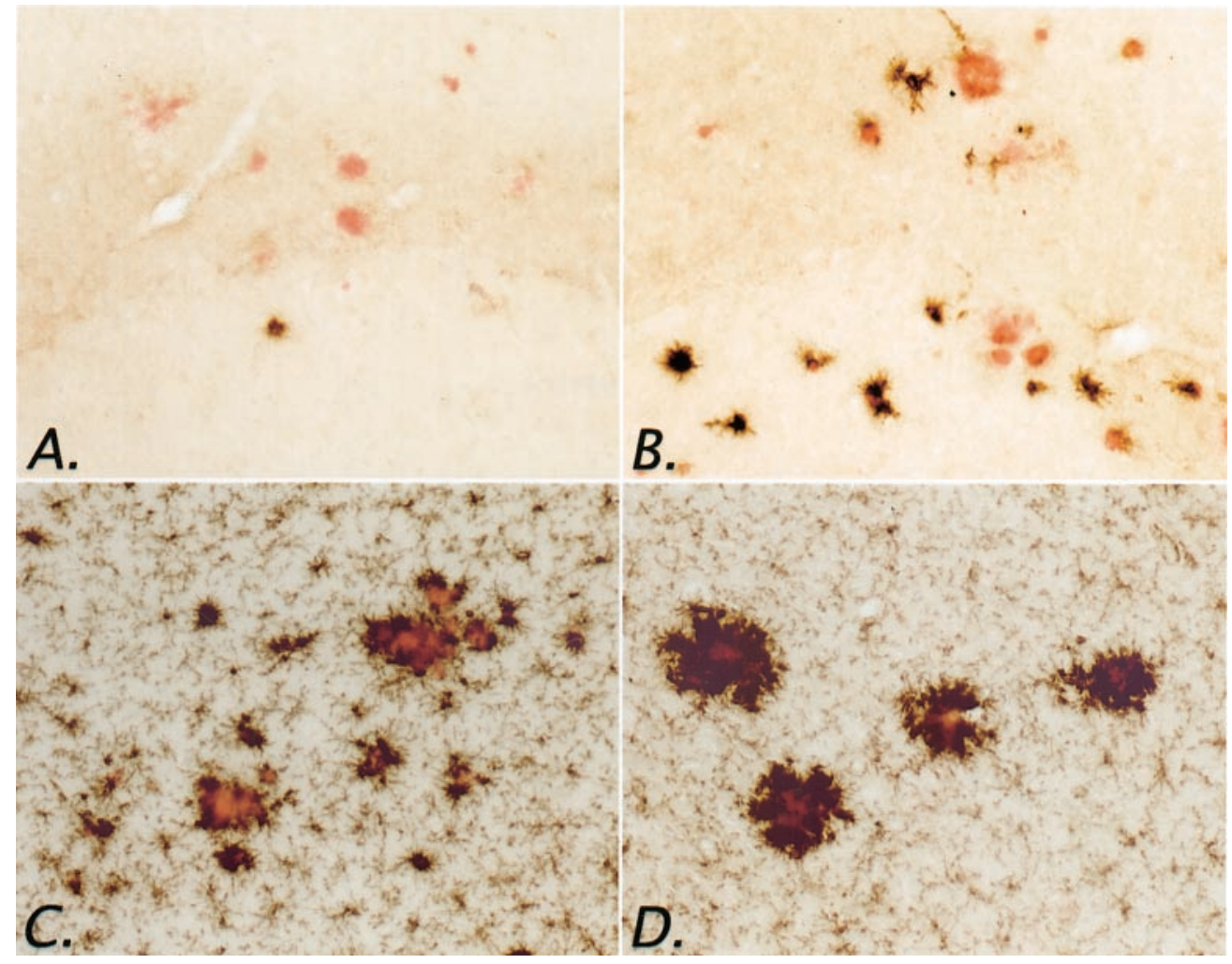

Figure 7. Effects of short-term NCX2216 treatment on microglial markers in APP + PS1 mice. Animals were treated with $7.5 \mathrm{mg} \cdot \mathrm{kg}^{-1} \cdot \mathrm{d}^{-1} \mathrm{NCX}-2216$ or vehicle for $14 \mathrm{~d}$ before they were killed. MHC-II immunohistochemistry of the frontal cortex of an APP+PS1 transgenic mouse treated with vehicle $(A)$ and NCX-2216 $(B)$ is shown. CD-11 immunohistochemistry of the frontal cortex of an APP +PS1 transgenic mouse treated with vehicle $(C)$ and NCX-2216 $(D)$ is also shown. Scale bar, $100 \mu \mathrm{m}$.
2216 does not completely clear brain amyloid, it should be noted that level of $\mathrm{A} \beta$ production in these doubly transgenic mice is 5to 15-fold higher than in mice expressing APP alone (Morgan et al., 2000). This amyloid-reducing effect of NCX-2216 is greater than that obtained with vaccination in the same mouse model (Morgan et al., 2000). To date, NCX-2216 is the most efficacious agent we have found in reducing $\mathrm{A} \beta$ loads.

We also observed activation of microglia in the immediate vicinity of fibrillar $\mathrm{A} \beta$ deposits by NCX-2216. This was evidenced by induction of MHC-II expression and increased staining for complement receptor-3. It should be noted that this increase in microglial activation occurred despite reduced Congo red-stained amyloid deposits (in chronically treated mice), which act as a stimulus for microglial activation as transgenic mice age (Masliah et al., 1996; Frautschy et al., 1998; Benzing et al., 1999; Stalder et al., 1999; Matsuoka et al., 2001). This outcome was in opposition to our original assumption that anti-inflammatory drugs would decrease the microglial activation caused by $\mathrm{A} \beta$ deposition.

The inflammation hypothesis of AD posits that hyperactive microglia are the proximal cause of AD-associated neurotoxicity and contribute directly to the neuropathology characteristic of the disease (McGeer and McGeer, 1998; Akiyama et al., 2000). A number of reports show that chronic NSAID use is associated with reduced risk for dementia (Breitner, 2000) and may even slow progression of the outward symptoms of AD (Rogers et al., 1993). At autopsy, a significant fraction of cognitively normal aged individuals present densities of amyloid plaques and neurofibrillary tangles consistent with a diagnosis of AD (Crystal et al., 1988; Davis et al., 1999). Mackenzie and Munoz (1998) report that microglial reactivity associated with amyloid pathology is reduced in cognitively normal arthritics taking anti-inflammatory compounds, suggesting that NSAIDs might reduce the risk of AD by inhibiting microglial activation. However, Lue et al. (1996,
2000) generally found low microglial activation in these "highplaque normal" cases, regardless of NSAID use. Halliday et al. (2000) failed to find reduced microglia reactivity in demented individuals taking NSAIDs.

In addition to the potential role of microglial activation causing damage in $\mathrm{AD}$, there is increasing evidence, at least in transgenic models of amyloid deposition, that activated microglia may remove amyloid deposits. In vitro, it is clear that microglia are capable of phagocytosing $\mathrm{A} \beta$ aggregates via scavenger $\mathrm{A}$ or receptors for advanced glycosylation endproducts (Shaffer et al., 1995; Ard et al., 1996; Paresce et al., 1996; Webster et al., 2000). In the presence of anti-A $\beta$ antibodies, Fc receptors may also mediate amyloid uptake in vitro or in situ (Bard et al., 2000; Brazil et al., 2000; Webster et al., 2001). Injections of $\mathrm{A} \beta$ amyloid into rat brain also elicit a phagocytic response by microglia, leading to removal of large fractions of the injected material (Frautschy et al., 1992; Weldon et al., 1998; Holcomb et al., 1999a). In transgenic mice, activation of microglia has been argued to be responsible for the reductions in $\mathrm{A} \beta$ deposition found with vaccination (Schenk et al., 1999; Wilcock et al., 2001) or with direct injection of anti-A $\beta$ antibodies (Bacskai et al., 2000); however, a peripheral action of antibodies in removing $\mathrm{A} \beta$ from brain has also been proposed (DeMattos et al., 2001). Furthermore, lipopolysaccharide (LPS) administration, which also activates microglia, results in reductions in $\mathrm{A} \beta$ deposition (DiCarlo et al., 2001). These data suggest that the increased microglia activation may have caused the reduced levels of amyloid in the transgenic mice treated with NCX-2216 by phagocytosis and clearance of the $\mathrm{A} \beta$ deposits.

The mechanism by which NCX-2216 leads to microglial activation is not clear. There are three potentially active components of the NCX-2216 molecule. The first is the NSAID moiety, flurbiprofen. The majority of research on the actions of NSAID on neural cells has been conducted using cells activated by chem- 

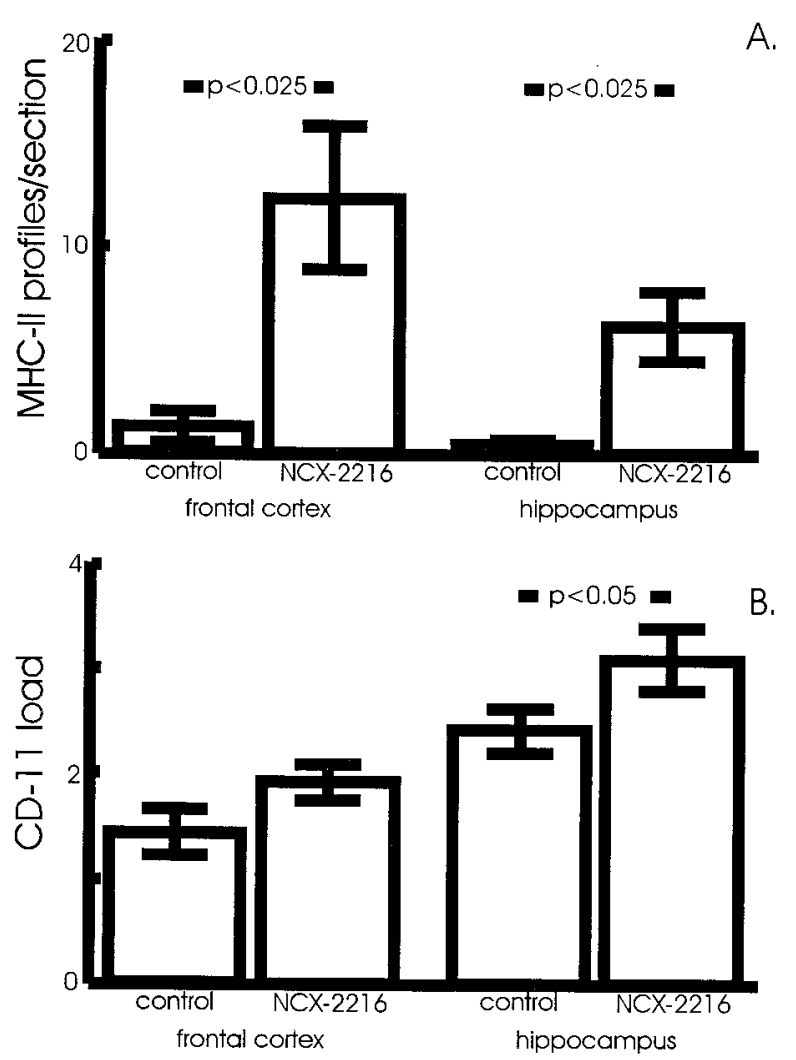

Figure 8. Measurement of the effects of short-term NCX-2216 treatment on microglial markers in APP+PS1 mice. Animals were treated with 7.5 $\mathrm{mg} \cdot \mathrm{kg}^{-1} \cdot \mathrm{d}^{-1} \mathrm{NCX}-2216$ or vehicle for $14 \mathrm{~d}$ before they were killed. Sections were stained with anti-MHC-II antibodies and Congo red, and positive microglial profiles were counted on systematic uniform random sections through the frontal cortex and hippocampus. Results are expressed as average number of MHC-II-positive microglial profiles per section in each region $(A)$. NCX-2216 treatment resulted in a $>10$-fold increase in the average number of MHC-II-positive profiles in both the frontal cortex and hippocampus when compared with vehicle-treated mice $(p<0.025)$. Sections were stained with anti-CR3 antibody and Congo red, and total immunoreactivity measurements of ICC-RP were calculated $(B)$. There is significantly greater total immunoreactivity of Congo red-associated ICC-RP in the hippocampus $(p<0.05)$; however, there is only a trend toward greater total immunoreactivity in the frontal cortex $(p<0.2)$.

ical irritants or the endotoxin LPS. Under these circumstances, NSAIDs reduce the inflammatory response. In young rats infused with LPS, even NCX-2216 acts like a typical NSAID and reduces microglia activation (Hauss-Wegrzyniak et al., 1999a,b). However, in naive mice, Prechel et al. (2000) reported the upregulation of a microglial marker, complement receptor-3, with indomethacin. Studies outside of the CNS have found that the COX product prostaglandin $\mathrm{E}_{2}\left(\mathrm{PGE}_{2}\right)$ normally maintains cells of monocytic origin, such as microglia, in a resting condition. Inhibition of constitutive COX activity by NSAIDs reduces $\mathrm{PGE}_{2}$ and disinhibits monocytes, resulting in activation of these cells (Young, 1994; Zicari et al., 1995). Indeed, in old rats, NCX-2216 increased the numbers of activated microglia in the presence of an LPS dose that had little effect of its own (HaussWegrzyniak et al., 1999a). It is possible that under certain circumstances, high brain levels of NSAIDs may activate microglia, as observed here (note that ibuprofen and celecoxib tended toward increased MHC-II staining as well). Little is known regarding the effects of the modifications present in NCX-2216 on the distribution of the drug into various tissues, particularly the

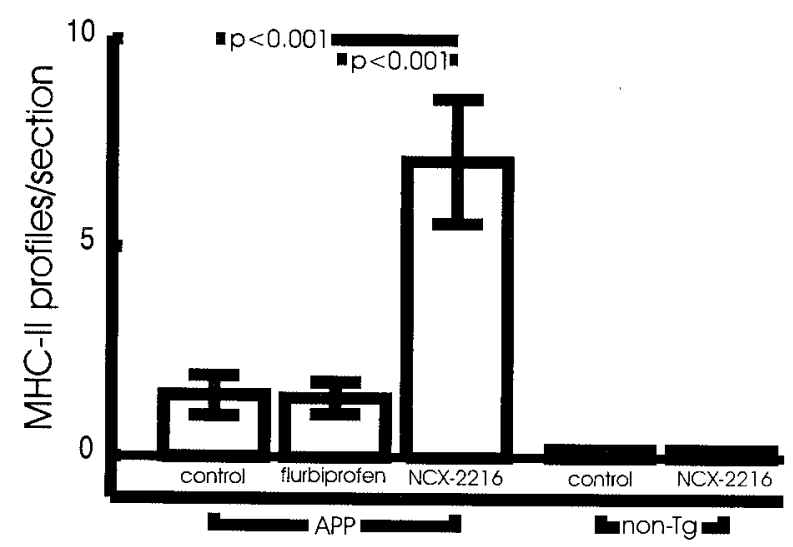

Figure 9. Measurement of MHC-II immunohistochemistry after acute treatment of APP transgenic and nontransgenic mice with NCX-2216, flurbiprofen, or vehicle. NCX-2216 $\left(7.5 \mathrm{mg} \cdot \mathrm{kg}^{-1} \cdot \mathrm{d}^{-1}\right)$ treatment of 12-month-old APP transgenic mice results in a significantly increased number of MHC-II-positive microglia compared with APP mice treated with either flurbiprofen $\left(5 \mathrm{mg} \cdot \mathrm{kg}^{-1} \cdot \mathrm{d}^{-1}\right)$ or vehicle $(p<0.001)$. Nontransgenic mice treated daily with either NCX-2216 or vehicle for 2 weeks demonstrate no detectable MHC-II-positive microglia.

brain. If one action is to enhance blood-brain-barrier penetration, this might explain the greater effects of NCX-2216 versus flurbiprofen alone. This issue is being addressed in ongoing studies.

The second component of the NCX-2216 molecule is ferulic acid, an antioxidant found in a number of fruits and vegetables (Graf, 1992). It is also used commercially to retard food spoilage. Yan et al. (2001) reported recently that pretreatment of mice with ferulic acid protected these mice from learning and memory deficits caused by intraventricular injections of $\mathrm{A} \beta$. Interestingly, these authors also found that the treatment of naive mice with ferulic acid could elevate GFAP and interleukin-1 (IL-1) levels, at least transiently.

A third possibility is that the slow generation of nitric oxide by NCX-2216 is conferring novel properties to the NSAID. In multiple instances, NO-releasing side chains attached to parent molecules result in more potent actions than the parent compound, or confer additional actions not found with the parent compound alone. For example, addition of an NO-releasing group to acetaminophen (a.k.a. paracetamol) adds antiinflammatory activity to this compound that is typically useful only for antipyretic and analgesic actions. The nitroacetaminophen even avoids the liver toxicity caused by high doses of acetaminophen alone (al Swayeh et al., 2000; Futter et al., 2001). Addition of an NO-releasing group to aspirin provides greater protection against restenosis and atherosclerosis in models of cardiovascular disease (Napoli et al., 2001) and, unlike aspirin alone, directly blocks IL-1 induction by inhibiting IL-1 $\beta$ converting enzyme and other caspases (Fiorucci et al., 2000). The inability of flurbiprofen to mimic the microglial activating properties of low-dose NCX-2216 in the short-term treatment studies implies some unique actions of the modified NSAID. This may result from the presence of ferulic acid, the NO-generating group, or both, in conjunction with the NSAID moiety. Future experiments will address this issue in more detail.

Given the multiple pathways for microglia activation in the brain and the complex interplay of stimuli present in the AD brain, it is likely that there are multiple states of microglial activation. As suggested by Raine (2000), it is plausible that the 
activation of immune system components in the AD brain may have benefits rather than exclusively detrimental effects. Roher and colleagues (Roher et al., 1993a,b; Kuo et al., 1998) have demonstrated that in end-stage Alzheimer's disease, the $\mathrm{A} \beta$ deposits have been chemically modified by racemization, isomerization, glycation, truncation, transglutamination, etc. These "hard" deposits may be difficult for microglia to clear from the tissue, leading to a condition of "frustrated phagocytosis" and induction of extreme activation states involving respiratory burst activity, among other potentially destructive reactions. This condition has been referred to by McGeer and McGeer (2001) as "autotoxicity" to distinguish it from other forms of glial activation. Importantly, it is likely that these extreme forms of microglial activation might be moderated by NSAIDs or other antiinflammatory agents, while leaving constitutive phagocytic functions intact. In this context, a potential mechanism of NSAID protection from AD may involve an early "release" of microglia from their resting state, before the hardening of the amyloid deposits, permitting effective phagocytic removal of $\mathrm{A} \beta$ at an early stage of deposition. Furthermore, NSAIDs have been shown to inhibit the expression of a wide variety of inflammatory mediators that have been suggested as potential pathological chaperones of $\mathrm{A} \beta$ deposition, such as the interleukins and tumor necrosis factors. By this mechanism alone, NSAIDs may be able to reduce $\mathrm{A} \beta$ deposition. This reduced $\mathrm{A} \beta$ load would decrease the likelihood of a more severe inflammatory cycle being initiated later in the disease process, when the deposits are more difficult to clear effectively. Importantly, the "soft" $\mathrm{A} \beta$ deposits of transgenic mice do not have the same degree of modification as those found in the end-stage AD brain (Kuo et al., 2001) This hypothesis would also predict that NSAID use years before the expected onset of dementia would have the greatest benefit in protecting from AD. From previous work we have published on spatial memory deficits in APP+PS1 mice (Morgan et al., 2000; Gordon et al., 2001), we anticipated that at 12 months of age, the transgenic mice given control diets would not be old enough to exhibit reliable learning deficits. Thus, we did not test this group of animals. We have initiated a second study in which we will treat mice to an age at which behavioral deficits are apparent in untreated transgenic mice, and expect to test them for spatial learning in the near future.

In conclusion, these data identify an unexpected activation of microglia by a nitro-NSAID in a mouse model of amyloid deposition. These results may impact the design of human trials to evaluate these drugs as therapeutics in AD patients. They also point to the possibility that some microglial activation in AD might be considered beneficial, when in the absence of stimulation of autotoxic reactions. We plan to extend these findings by comparing NCX-2216 and its component parts in additional long-term studies examining the functional, behavioral, and histopathological consequences of such treatments in these transgenic models of amyloid deposition.

\section{REFERENCES}

Akiyama H, Barger S, Barnum S, Bradt B, Bauer J, Cole GM, Cooper NR, Eikelenboom P, Emmerling M, Fiebich BL, Finch CE, Frautschy S, Griffin WS, Hampel H, Hull M, Landreth G, Lue L, Mrak R, Mackenzie IR, McGeer PL, et al (2000) Inflammation and Alzheimer's disease. Neurobiol Aging 21:383-421.

al Swayeh OA, Futter LE, Clifford RH, Moore PK (2000) Nitroparacetamol exhibits anti-inflammatory and anti-nociceptive activity. $\mathrm{Br} \mathbf{J}$ Pharmacol 130:1453-1456.

Ard MD, Cole GM, Wei J, Mehrle AP, Fratkin JD (1996) Scavenging of Alzheimer's amyloid $\beta$-protein by microglia in culture. J Neurosci Res 43:190-202.
Bacskai BJ, Kajdasz ST, Christie RH, Carter, C, Games, D, Seubert, P, Schenk, D, Hyman B (2000) Anti-amyloid- $\beta$ antibodies promote clearance of amyloid- $\beta$ deposits imaged in vivo in PDAPP mice. Soc Neurosci Abstr 26:1059.

Bard F, Cannon C, Barbour R, Burke RL, Games D, Grajeda H, Guido T, Hu K, Huang J, Johnson-Wood K, Khan K, Kholodenko D, Lee M, Lieberburg I, Motter R, Nguyen M, Soriano F, Vasquez N, Weiss K, Welch B, et al (2000) Peripherally administered antibodies against amyloid $\beta$-peptide enter the central nervous system and reduce pathology in a mouse model of Alzheimer disease. Nat Med 6:916-919.

Benzing WC, Wujek JR, Ward EK, Schaffer D, Ashe KH, Younkin SG, Brunden KR (1999) Evidence for glial-mediated inflammation in APPsw transgenic mice. Neurobiol Aging 20:581-590.

Brazil MI, Chung H, Maxfield FR (2000) Effects of incorporation of immunoglobulin $\mathrm{G}$ and complement component $\mathrm{C} 1 \mathrm{q}$ on uptake and degradation of Alzheimer's disease amyloid fibrils by microglia. J Biol Chem 275:16941-16947.

Breitner JC (1996) The role of anti-inflammatory drugs in the prevention and treatment of Alzheimer's disease. Annu Rev Med 47:401-411.

Breitner JC (2000) Epidemiologic clues to the causes and routes to prevention of Alzheimer disease. J Neural Transm Suppl 59:251-254.

Chowdhary S, Townend JN (2001) Nitric oxide and hypertension: not just an endothelium-derived relaxing factor! J Hum Hypertens 15:219-227.

Chung H, Brazil MI, Soe TT, Maxfield FR (1999) Uptake, degradation, and release of fibrillar and soluble forms of Alzheimer's amyloid $\beta$-peptide by microglial cells. J Biol Chem 274:32301-32308.

Crystal H, Dickson D, Fuld P, Masur D, Scott R, Mehler M, Masdeu J, Kawas C, Aronson M, Wolfson L (1988) Clinico-pathological studies in dementia: nondemented subjects with pathologically confirmed Alzheimer's disease. Neurology 38:1682-1687.

Davis DG, Schmitt FA, Wekstein DR, Markesbery WR (1999) Alzheimer neuropathologic alterations in aged cognitively normal subjects. J Neuropathol Exp Neurol 58:376-388.

Del Soldato P, Sorrentino R, Pinto A (1999) NO-aspirins: a class of new anti-inflammatory and antithrombotic agents. Trends Pharmacol Sci 20:319-323

DeMattos RB, Bales KR, Cummins DJ, Dodart JC, Paul SM, Holtzman DM (2001) Peripheral anti-A $\beta$ antibody alters CNS and plasma A $\beta$ clearance and decreases brain $A \beta$ burden in a mouse model of Alzheimer's disease. Proc Natl Acad Sci USA 98:8850-8855.

DiCarlo G, Wilcock D, Henderson D, Gordon M, Morgan D (2001) Intrahippocampal LPS injections reduce A $\beta$ load in APP + PS1 transgenic mice. Neurobiol Aging 22:1007-1012.

Duff K, Eckman C, Zehr C, Yu X, Prada CM, Perez-tur J, Hutton M, Buee L, Harigaya Y, Yager D, Morgan D, Gordon MN, Holcomb L, Refolo L, Zenk B, Hardy J, Younkin S (1996) Increased amyloid$\beta 42(43)$ in brains of mice expressing mutant presenilin 1 . Nature 383:710-713.

Fiorucci S, Santucci L, Cirino G, Mencarelli A, Familiari L, Soldato PD, Morelli A (2000) IL-1 $\beta$-converting enzyme is a target for nitric oxidereleasing aspirin: new insights in the antiinflammatory mechanism of nitric oxide-releasing nonsteroidal antiinflammatory drugs. J Immunol 165:5245-5254.

Frackowiak J, Wisniewski HM, Wegiel J, Merz GS, Iqbal K, Wang KC (1992) Ultrastructure of the microglia that phagocytose amyloid and the microglia that produce $\beta$-amyloid fibrils. Acta Neuropathol (Berl) $84: 225-233$

Frautschy SA, Cole GM, Baird A (1992) Phagocytosis and deposition of vascular $\beta$-amyloid in rat brains injected with Alzheimer $\beta$-amyloid. Am J Pathol 140:1389-1399.

Frautschy SA, Yang F, Irrizarry M, Hyman B, Saido TC, Hsiao K, Cole GM (1998) Microglial response to amyloid plaques in APPsw transgenic mice. Am J Pathol 152:307-317.

Futter LE, al Swayeh OA, Moore PK (2001) A comparison of the effect of nitroparacetamol and paracetamol on liver injury. Br J Pharmacol 132:10-12.

Gordon MN, Schreier WA, Ou X, Holcomb LA, Morgan DG (1997) Exaggerated astrocyte reactivity after nigrostriatal deafferentation in the aged rat. J Comp Neurol 388:106-119.

Gordon MN, Holcomb LA, Jantzen PT, DiCarlo G, Wilcock D, Connor K, Melachrino JO, O'Callaghan JP, Morgan D (2002) Time course of the development of Alzheimer-like pathology in the doubly transgenic mPS1+ mAPP mouse. Exp Neurol 173:183-195.

Graf E (1992) Antioxidant potential of ferulic acid. Free Radic Biol Med 13:435-448.

Grassi S, Pettorossi VE (2001) Synaptic plasticity in the medial vestibular nuclei: role of glutamate receptors and retrograde messengers in rat brainstem slices. Prog Neurobiol 64:527-553.

Halliday GM, Shepherd CE, McCann H, Reid WG, Grayson DA, Broe GA, Kril JJ (2000) Effect of anti-inflammatory medications on neuropathological findings in Alzheimer disease. Arch Neurol 57:831-836.

Hauss-Wegrzyniak B, Vraniak P, Wenk GL (1999a) The effects of a novel NSAID on chronic neuroinflammation are age dependent. Neurobiol Aging 20:305-313. 
Hauss-Wegrzyniak B, Willard LB, Del Soldato P, Pepeu G, Wenk GL (1999b) Peripheral administration of novel anti-inflammatories can attenuate the effects of chronic inflammation within the CNS. Brain Res 815:36-43.

Holcomb LA, Gordon MN, McGowan E, Yu X, Benkovic S, Jantzen P, Wright K, Saad I, Mueller R, Morgan D, Sanders S, Zehr C, O'Campo K, Hardy J, Prada CM, Eckman C, Younkin S, Hsiao K, Duff K (1998) Accelerated Alzheimer-type phenotype in transgenic mice carrying both mutant amyloid precursor protein and presenilin 1 transgenes. Nat Med 4:97-100.

Holcomb LA, Gordon MN, Benkovic SA, Morgan DG (1999a) A $\beta$ and perlecan in rat brain. Glial activation, gradual clearance and limited neurotoxicity. Mech Ageing Dev 112:135-152.

Holcomb LA, Gordon MN, Jantzen P, Hsiao K, Duff K, Morgan D (1999b) Behavioral changes in transgenic mice expressing both amyloid precursor protein and presenilin-1 mutations: lack of association with amyloid deposits. Behav Gen 29:177-185.

Hsiao K, Chapman P, Nilsen S, Eckman C, Harigaya Y, Younkin S, Yang $\mathrm{F}$, Cole G (1996) Correlative memory deficits, A $\beta$ elevation, and amyloid plaques in transgenic mice. Science 274:99-102.

James DS (1999) The multisystem adverse effects of NSAID therapy. J Am Osteopath Assoc 99:S1-S7.

Kreutzberg GW (1996) Microglia: a sensor for pathological events in the CNS. Trends Neurosci 19:312-318.

Kuo YM, Webster S, Emmerling MR, De Lima N, Roher AE (1998) Irreversible dimerization/tetramerization and post-translational modifications inhibit proteolytic degradation of $A \beta$ peptides of Alzheimer's disease. Biochim Biophys Acta 1406:291-298.

Kuo YM, Kokjohn TA, Beach TG, Sue LI, Brune D, Lopez JC, Kalback WM, Abramowski D, Sturchler-Pierrat C, Staufenbiel M, Roher AE (2001) Comparative analysis of amyloid- $\beta$ chemical structure and amyloid plaque morphology of transgenic mouse and Alzheimer's disease brains. J Biol Chem 276:12991-12998.

Lim GP, Yang F, Chu T, Chen P, Beech W, Teter B, Tran T, Ubeda O, Ashe KH, Frautschy SA, Cole GM (2000) Ibuprofen suppresses plaque pathology and inflammation in a mouse model for Alzheimer's disease. J Neurosci 20:5709-5714.

Lue L, Brachova L, Civin H, Rogers J (1996) Inflammation, A $\beta$ deposition, and neurofibrillary tangle formation as correlates of Alzheimer's disease neurodegeneration. J Neuropathol Exp Neurol 55:1083-1088.

Mackenzie IR (1996) Antiinflammatory drugs in the treatment of Alzheimer's disease. J Rheumatol 23:806-808.

Mackenzie IR, Munoz DG (1998) Nonsteroidal anti-inflammatory drug use and Alzheimer-type pathology in aging. Neurology 50:986-990.

Masliah E, Sisk A, Mallory M, Mucke L, Schenk D, Games D (1996) Comparison of neurodegenerative pathology in transgenic mice overexpressing V717F $\beta$-amyloid precursor protein and Alzheimer's disease. J Neurosci 16:5795-5811.

Matsuoka Y, Picciano M, Malester B, LaFrancois J, Zehr C, Daeschner JM, Olschowka JA, Fonseca MI, O'Banion MK, Tenner AJ, Lemere CA, Duff K (2001) Inflammatory responses to amyloidosis in a transgenic mouse model of Alzheimer's disease. Am J Pathol 158:1345-1354.

McGeer EG, McGeer PL (1998) The importance of inflammatory mechanisms in Alzheimer disease. Exp Gerontol 33:371-378.

McGeer P, McGeer EG (2001) Inflammation, autotoxicity, and Alzheimer's disease. Neurobiol Aging 22:799-809.

McGowan E, Sanders S, Iwatsubo T, Takeuchi A, Saido T, Zehr C, Yu X, Uljon S, Wang R, Mann D, Dickson D, Duff K (1999) Amyloid phenotype characterization of transgenic mice overexpressing both mutant amyloid precursor protein and mutant presenilin 1 transgenes. Neurobiol Dis 6:231-244.

Minghetti L, Polazzi E, Nicolini A, Greco A, Levi G (1999) Possible role of microglial prostanoids and free radicals in neuroprotection and neurodegeneration. Adv Exp Med Biol 468:109-119.

Moore S, Thanos S (1996) The concept of microglia in relation to central nervous system disease and regeneration. Prog Neurobiol 48:441-460.

Morgan D, Diamond DM, Gottschall PE, Ugen KE, Dickey C, Hardy J, Duff K, Jantzen P, DiCarlo G, Wilcock D, Connor K, Hatcher J, Hope C, Gordon M, Arendash GW (2000) A $\beta$ peptide vaccination prevents memory loss in an animal model of Alzheimer's disease Nature 408:982-985.

Napoli C, Ignarro LJ (2001) Nitric oxide and atherosclerosis. Nitric Oxide 5:88-97.

Napoli C, Cirino G, Del Soldato P, Sorrentino R, Sica V, Condorelli M, Pinto A, Ignarro LJ (2001) Effects of nitric oxide-releasing aspirin versus aspirin on restenosis in hypercholesterolemic mice. Proc Natl Acad Sci USA 98:2860-2864.

Navarra P, Dello RC, Mancuso C, Preziosi P, Grossman A (2000) Gaseous neuromodulators in the control of neuroendocrine stress axis. Ann NY Acad Sci 917:638-646.

Paresce DM, Ghosh RN, Maxfield FR (1996) Microglial cells internalize aggregates of the Alzheimer's disease amyloid $\beta$-protein via a scavenger receptor. Neuron 17:553-565.

Prechel MM, Ding C, Washington RL, Kolodziej MS, Young MR (2000) In vivo indomethacin treatment causes microglial activation in adult mice. Neurochem Res 25:357-362.

Raine CS (2000) Inflammation in Alzheimer's disease: a view from the periphery. Neurobiol Aging 21:437-440.

Rogers J, Kirby LC, Hempelman SR, Berry DL, McGeer PL, Kaszniak AW, Zalinski J, Cofiled C, Mansukhani L, Wilson P, Kogan F (1993) Clinical trail of indomethacin in Alzheimer's disease. Neurology 43:1609-1611.

Rogers J, Webster S, Lue LF, Brachova L, Civin WH, Emmerling M, Shivers B, Walker D, McGeer P (1996) Inflammation and Alzheimer's disease pathogenesis. Neurobiol Aging 17:681-686.

Roher AE, Lowenson JD, Clarke S, Wolkow C, Wang R, Cotter RJ, Reardon IM, Zurcher-Neely HA, Heinrikson RL, Ball MJ (1993a) Structural alterations in the peptide backbone of $\beta$-amyloid core protein may account for its deposition and stability in Alzheimer's disease. J Biol Chem 268:3072-3083.

Roher AE, Palmer KC, Yurewicz EC, Ball MJ, Greenberg BD (1993b) Morphological and biochemical analyses of amyloid plaque core proteins purified from Alzheimer disease brain tissue. J Neurochem 61:1916-1926.

Sasaki A, Yamaguchi H, Ogawa A, Sugihara S, Nakazato Y (1997) Microglial activation in early stages of amyloid $\beta$ protein deposition. Acta Neuropathol (Berl) 94:316-322.

Schenk D, Barbour R, Dunn W, Gordon G, Grajeda H, Guido T, Hu K, Huang J, Johnson-Wood K, Khan K, Kholodenko D, Lee M, Liao Z, Lieberburg I, Motter R, Mutter L, Soriano F, Shopp G, Vasquez N, Vandevert C, et al (1999) Immunization with amyloid- $\beta$ attenuates Alzheimer-disease-like pathology in the PDAPP mouse. Nature 400:173-177.

Shaffer LM, Dority MD, Gupta-Bansal R, Frederickson RC, Younkin SG, Brunden KR (1995) Amyloid $\beta$ protein $(A \beta)$ removal by neuroglial cells in culture. Neurobiol Aging 16:737-745.

Snowdon DA (1997) Aging and Alzheimer's disease: lessons from the Nun Study. Gerontologist 37:150-156.

Stalder M, Phinney A, Probst A, Sommer B, Staufenbiel M, Jucker M (1999) Association of microglia with amyloid plaques in brains of APP23 transgenic mice. Am J Pathol 154:1673-1684.

Wallace JL, Reuter B, Cicala C, McKnight W, Grisham MB, Cirino G (1994) Novel nonsteroidal anti-inflammatory drug derivatives with markedly reduced ulcerogenic properties in the rat. Gastroenterology 107:173-179.

Webster SD, Yang AJ, Margol L, Garzon-Rodriguez W, Glabe CG Tenner AJ (2000) Complement component C1q modulates the phagocytosis of A $\beta$ by microglia. Exp Neurol 161:127-138.

Webster SD, Galvan MD, Ferran E, Garzon-Rodriguez W, Glabe CG, Tenner AJ (2001) Antibody-mediated phagocytosis of the amyloid $\beta$-peptide in microglia is differentially modulated by $\mathrm{C} 1 \mathrm{q}$. J Immunol 166:7496-7503.

Wegiel J, Chauhan A, Wisniewski HM, Nowakowski J, Wang KC, Le Vine $H$ (1996) Promotion of synthetic amyloid $\beta$-peptide fibrillization by cell culture media and cessation of fibrillization by serum. Neurosci Lett 211:151-154.

Weldon DT, Rogers SD, Ghilardi JR, Finke MP, Cleary JP, O'Hare E, Esler WP, Maggio JE, Mantyh PW (1998) Fibrillar $\beta$-amyloid induces microglial phagocytosis, expression of inducible nitric oxide synthase, and loss of a select population of neurons in the rat CNS in vivo. J Neurosci 18:2161-2173.

West M, Slomianka L, Gunderson H (1991) Unbiased stereological estimation of the total number of neurons in the subdivisions of the rat hippocampus using the optical fractionator. Anat Rec 231:482-497.

Wilcock DM, Gordon MN, Ugen KE, Gottschall PE, DiCarlo G, Dickey C, Boyett KW, Jantzen PT, Connor KE, Melachrino J, Hardy J, Morgan D (2001) Number of A $\beta$ inoculations in APP + PS1 transgenic mice influences antibody titers, microglial activation, and congophilic plaque levels. DNA Cell Biol 20:731-736.

Wyss-Coray T, Lin C, Yan F, Yu GQ, Rohde M, McConlogue L, Masliah E, Mucke L (2001) TGF- $\beta 1$ promotes microglial amyloid- $\beta$ clearance and reduces plaque burden in transgenic mice Nat Med 7:612-618.

Yan JJ, Cho JY, Kim HS, Kim KL, Jung JS, Huh SO, Suh HW, Kim YH, Song DK (2001) Protection against $\beta$-amyloid peptide toxicity in vivo with long-term administration of ferulic acid. $\mathrm{Br} \mathrm{J}$ Pharmacol 133:89-96.

Young MR (1994) Eicosanoids and the immunology of cancer. Cancer Metastasis Rev 13:337-348.

Zicari A, Lipari M, Di Renzo L, Salerno A, Losardo A, Pontieri GM (1995) Stimulation of macrophages with IFN $\gamma$ or TNF $\alpha$ shuts off the suppressive effect played by PGE2. Int J Immunopharmacol 17:779786. 